\title{
GC-MS analysis of root methanolic extract of Gynochthodes ridsdalei Razafim. and B. Bremer, an endemic, endangered species of southern Western Ghats of India
}

\author{
Renji R. Nair and A. Gangaprasad* \\ Plant Tissue Culture and Molecular Biology Lab, Department of Botany, University of Kerala, Thiruvananthapuram 695581, India
}

Article history

Received: 08 February 2018

Accepted: 31 March 2018

Published: 05 April 2018

(c) Nair and Gangaprasad (2018)

\section{Editor}

K K Sabu

Publisher

Horizon e-Publishing Group

Correspondence

A. Gangaprasad

$凶$ agangaprasad@yahoo.com

\begin{abstract}
The present investigation was carried out to determine the presence of biologically active components in the root methanolic extract of Gynochthodes ridsdalei using Gas Chromatography-Mass Spectrometry (GC-MS) analysis. Fresh root of G. ridsdalei collected from the forest areas of Ponmudi hills of Thiruvananthapuram district of Kerala State, India was used for the study. The active principles with their retention time, peak area, molecular weight and molecular formula of the compounds were detected. The analysis revealed the presence of 26 components. The components were identified by comparing their retention time and peak area with that of literature available and by the interpretation of mass spectra.
\end{abstract}

\section{Keywords}

Gynochthodes ridsdalei; endangered; Southern Western Ghats; root extract; gas chromatography- mass spectrometry

\section{Citation}

Nair R R, Gangaprasad A. GC-MS analysis of root methanolic extract of Gynochthodes ridsdalei Razafim. and $\mathrm{B}$. Bremer, an endemic, endangered species of southern Western Ghats of India. Plant Science Today 2018;5(2):64-67. https://dx.doi.org/10.14719/pst.2018.5.2.384

\section{Introduction}

Plants are important sources of bioactive components which play a dominant role in the maintenance of human health (1). Knowledge about the chemical constituents of plants is necessary not only for the discovery of new therapeutics but also for transferring the information of new sources of economic phytocomponents for the synthesis of complex chemical molecules as well as for recognising the importance of folkloric remedies (2).
Gynochthodes ridsdalei (Syn: Morinda reticulata) is a large woody climbing shrub with coriaceous reticulate leaves, that belongs to the family Rubiaceae. This is an endemic and endangered species of southern Western Ghats (3). This plant forms an important constituent in a variety of herbal formulations in traditional medicine (4). The genus Gynochthodes (Syn: Morinda) is known to contain substantial amounts of anthraquinones particularly in the roots (5) that have been used for dyeing purpose. The present 
study has focused on the GC-MS analysis of G. ridsdalei roots.

Gas Chromatography-Mass Spectrometry (GC-MS) analysis can be used for the direct analysis of bioactive components in traditional medicine and for separation and analysis of multicomponent mixtures such as essential oils, solvents and hydrocarbons (1).

\section{Materials and Methods}

\section{Collection of plant material}

Fresh roots of Gynochthodes ridsdalei were collected from the forest areas of Ponmudi Hills of Thiruvananthapuram District of Kerala Sate, India. The taxonomical identification of the plant was done using authentic literature $(6,7)$. A voucher specimen was deposited in the Herbarium of Department of Botany, University of Kerala, Kariavattom (KUBH No. 8095).

\section{Preparation of plant extract}

The collected roots were washed thoroughly and chopped into small pieces before shade drying under room temperature for two weeks. The dried material was then milled into coarse powder by mechanical grinder and stored in air tight bottles until further use. About $10 \mathrm{gm}$ of the powdered root sample was subjected to Soxhlet extraction for 6-7 hrs using $200 \mathrm{ml}$ methanol. The extract was concentrated using rotary evaporator (Superfit rotavap) under reduced pressure and stored in the refrigerator until further use. Two microliters of the extract was employed in GC-MS analysis, for the identification of compounds.

\section{GC-MS analysis}

The analysis of the extract was performed using GC-MS (Model: GC MS-QP 2010, Shimadzu, Japan) equipped with a VF-5ms fused silica capillary column of $30 \mathrm{~m}$ length, $0.25 \mathrm{~mm}$ diameter and 0.25 $\mu \mathrm{m}$ film thickness. For GC-MS analysis, electron ionization system with ionization energy of $70 \mathrm{eV}$ was used. The carrier gas used was helium (99.9\%), at a constant flow rate of $1.2 \mathrm{ml} / \mathrm{min}$. Injector and mass transfer line temperature were set to $200^{\circ} \mathrm{C}$ and $255^{\circ} \mathrm{C}$ respectively. The oven temperature was set from 70 to $220^{\circ} \mathrm{C}$ at $10^{\circ} \mathrm{C} / \mathrm{min}$ for $9 \mathrm{~min}$, and finally raised to $300^{\circ} \mathrm{C}$. Two microliters of the sample was injected in a split mode with a scan range of $40-1000 \mathrm{~m} / \mathrm{z}$. The total running time of GC-MS was $35 \mathrm{~min}$. The relative percentage amount of each component was calculated by comparing its average peak area normalization value (8).

\section{Identification of the components}

Interpretation of mass spectrum obtained from GC-MS was done using the database of National Institute Standard and Technology (NIST) and Wiley Spectra Libraries. The spectrum of the unknown component was compared with that of the spectrum of known components, which was stored in the NIST08 library source (9). The name, molecular weight and molecular mass of the identified compounds were further confirmed by comparing their retention indices with that of literature data. For quantitative analysis, the concentration of compounds (\%) were calculated by combining their corresponding chromatographic peak area.

\section{Results and Discussion}

The bioactive components present in the root methanolic extract of $G$. ridsdalei were identified by GC-MS analysis. The gas chromatogram shows the relative concentrations of various compounds eluted as a function of their retention time (Fig. 1). Identification of the compounds was done by comparing their mass spectra and retention indices with those given in the literature and with the authentic samples. The active principles with their retention time (RT), peak area (\%) and biological activities are listed by the order of their retention times in Table 1.

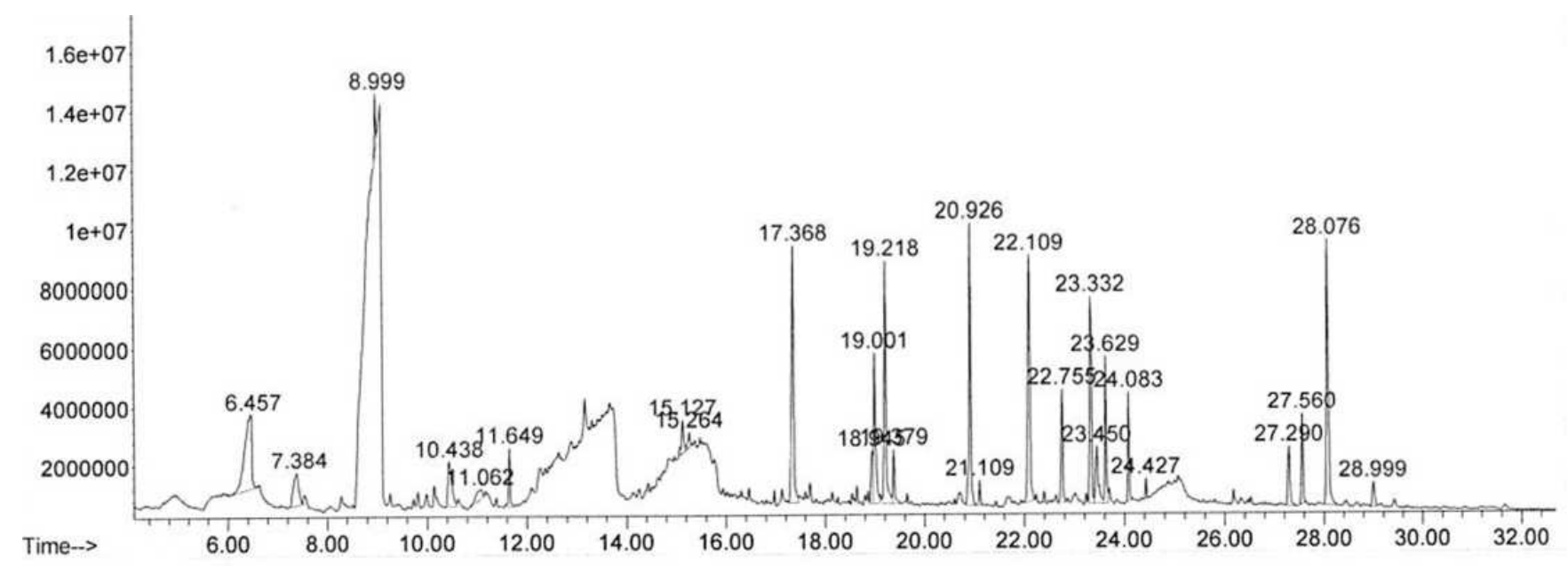

Fig 1. GC-MS Chromatogram of methanolic root extract of Gynochthodes ridsdalei 
Table 1. Phytocomponents identified in the methanolic root extract of Gynochthodes ridsdalei by GC-MS analysis

\begin{tabular}{|c|c|c|c|c|c|c|c|}
\hline $\begin{array}{l}\text { Sl. } \\
\text { No. }\end{array}$ & $\begin{array}{l}\text { Retentio } \\
\text { n time }\end{array}$ & $\begin{array}{l}\text { Peak } \\
\text { area\% }\end{array}$ & Name of the compound & $\begin{array}{l}\text { Molecular } \\
\text { formula }\end{array}$ & $\begin{array}{l}\text { Molecula } \\
\text { r weight }\end{array}$ & $\begin{array}{l}\text { Nature of } \\
\text { compound }\end{array}$ & Uses \\
\hline 1 & 6.47 & 9.35 & Maltol & $\mathrm{C}_{6} \mathrm{H}_{6} \mathrm{O}_{3}$ & 126.1133 & Ketone & Flavour enhancer \\
\hline 2 & 7.385 & 2.94 & $\begin{array}{l}\text { 4H-Pyran-4-one, 2,3-dihydro- } \\
\text { 3,5-di hydroxy-6-methyl- }\end{array}$ & $\mathrm{C}_{6} \mathrm{H}_{8} \mathrm{O}_{4}$ & 144.126 & $\begin{array}{l}\text { Organic } \\
\text { compound }\end{array}$ & Unknown \\
\hline 3 & 8.997 & 1.11 & 4-Mercaptophenol & $\mathrm{C}_{6} \mathrm{H}_{6} \mathrm{OS}$ & 126.176 & Phenol & Unknown \\
\hline 4 & 10.438 & 2.84 & Phenol 2,6-dimethoxy & $\mathrm{C}_{11} \mathrm{H}_{14} \mathrm{O}_{3}$ & 194.230 & $\begin{array}{l}\text { Phenol } \\
\text { Eugenol }\end{array}$ & $\begin{array}{l}\text { Perfumery } \\
\text { Dentistry }\end{array}$ \\
\hline 5 & 11.062 & 1.54 & $\begin{array}{l}\text { 2-Hydroxyhexadecyl } \\
\text { butanoate }\end{array}$ & $\mathrm{C}_{20} \mathrm{H}_{40} \mathrm{O}_{3}$ & 328.529 & Ester & Unknown \\
\hline 6 & 11.649 & 1.54 & 4-Aminoresorcinol & $\mathrm{C}_{6} \mathrm{H}_{8} \mathrm{ClNO}_{2}$ & 161.59 & Amine & Unknown \\
\hline 7 & 15.126 & 1.24 & 4-Methylphenylthioacetone & $\mathrm{C}_{10} \mathrm{H}_{12} \mathrm{OS}$ & 180.27 & Acetone & Unknown \\
\hline 8 & 15.267 & 0.51 & 3-Deoxy-d-mannoic lactone & $\mathrm{C}_{6} \mathrm{H}_{10} \mathrm{O}_{5}$ & 162.14 & Ester & Unknown \\
\hline 9 & 17.369 & 10.16 & Hexadecanoic acid & $\mathrm{C}_{16} \mathrm{H}_{32} \mathrm{O}_{2}$ & 256.4241 & Palmitic acid & $\begin{array}{l}\text { Antioxidant } \\
\text { Hypocholestero- } \\
\text { mic, Nematicide }\end{array}$ \\
\hline 10 & 18.994 & 1.47 & 9,12-Octadecadienoic acid & $\mathrm{C}_{18} \mathrm{H}_{36} \mathrm{O}_{2}$ & 284.4772 & Stearic acid & $\begin{array}{l}\text { Dietary } \\
\text { supplements }\end{array}$ \\
\hline 11 & 19.004 & 5.32 & Oleic Acid & $\mathrm{C}_{18} \mathrm{H}_{36} \mathrm{O}_{2}$ & 284.4772 & Fatty acid & $\begin{array}{l}\text { Reducing blood } \\
\text { pressure }\end{array}$ \\
\hline 12 & 19.219 & 8.13 & 9-Octadecanoic acid & $\mathrm{C}_{18} \mathrm{H}_{36} \mathrm{O}_{2}$ & 284.4772 & Stearic acid & $\begin{array}{l}\text { Dietary } \\
\text { supplements }\end{array}$ \\
\hline 13 & 19.383 & 1.43 & 9-Octadecanamide & $\mathrm{C}_{18} \mathrm{H}_{35} \mathrm{NO}$ & 281.4766 & Amide & $\begin{array}{l}\text { Depression, Sleep } \\
\text { disorders }\end{array}$ \\
\hline 14 & 20.928 & 8.11 & 9-Octadecenamide & $\mathrm{C}_{18} \mathrm{H}_{35} \mathrm{NO}$ & 281.4766 & Amide & $\begin{array}{l}\text { Depression, Sleep } \\
\text { disorder }\end{array}$ \\
\hline 15 & 21.106 & 0.51 & 9-Octadecanamide & $\mathrm{C}_{18} \mathrm{H}_{35} \mathrm{NO}$ & 281.4766 & Amide & $\begin{array}{l}\text { Depression, Sleep } \\
\text { disorders }\end{array}$ \\
\hline 16 & 22.109 & 9.68 & $\begin{array}{l}\text { 9,10-Anthracenedione, l- } \\
\text { hydroxy-2-(hydroxymethyl)- }\end{array}$ & $\mathrm{C}_{15} \mathrm{H}_{10} \mathrm{O}_{4}$ & 254.238 & Anthraquinone & $\begin{array}{l}\text { Dyes, Medicinal } \\
\text { importance }\end{array}$ \\
\hline 17 & 22.755 & 3.09 & $\begin{array}{l}\text { 9,10-Anthracenedione, 1,8- } \\
\text { dihydrox y-3-methyl- }\end{array}$ & $\mathrm{C}_{18} \mathrm{H}_{18} \mathrm{~N}_{2} \mathrm{O}_{4}$ & 326.346 & Anthraquinone & $\begin{array}{l}\text { Dyes, Medicinal } \\
\text { importance }\end{array}$ \\
\hline 18 & 22.335 & 7.22 & Pyrrolo (3,2, F)-9-one & $\mathrm{C}_{9} \mathrm{H}_{7} \mathrm{~N}$ & 129.16 & $\begin{array}{l}\text { Heterocyclic } \\
\text { aromatic } \\
\text { organic } \\
\text { compound }\end{array}$ & $\begin{array}{l}\text { Manufacture of } \\
\text { dyes }\end{array}$ \\
\hline 19 & 23.453 & 2.62 & Oleic acid & $\mathrm{C}_{18} \mathrm{H}_{34} \mathrm{O}_{2}$ & 282.4614 & Fatty acid & $\begin{array}{l}\text { Reducing blood } \\
\text { pressure }\end{array}$ \\
\hline 20 & 23.632 & 3.64 & Octadecanoic acid & $\mathrm{C}_{18} \mathrm{H}_{36} \mathrm{O}_{2}$ & 284.4772 & Stearic acid & $\begin{array}{l}\text { Dietary } \\
\text { supplements }\end{array}$ \\
\hline 21 & 24.085 & 2.44 & 13-Docosenamide & $\mathrm{C}_{22} \mathrm{H}_{43} \mathrm{NO}$ & 337.5829 & $\begin{array}{l}\text { Erucic acid } \\
\text { (Fatty acid) }\end{array}$ & $\begin{array}{l}\text { Lubricant, } \\
\text { Biodiesel fuel } \\
\text { precursor }\end{array}$ \\
\hline 22 & 24.427 & 0.44 & Squalene & $\mathrm{C}_{30} \mathrm{H}_{50}$ & 410 & Triterpene & $\begin{array}{l}\text { Antimicrobial, } \\
\text { Antioxidant, Anti } \\
\text { tumour }\end{array}$ \\
\hline 23 & 27.287 & 2.17 & Campesterol & $\mathrm{C}_{28} \mathrm{H}_{48} \mathrm{O}$ & 400.69 & Phytosterol & $\begin{array}{l}\text { Lowering } \\
\text { cholesterol }\end{array}$ \\
\hline 24 & 27.561 & 2.68 & Stigmasterol & $\mathrm{C}_{29} \mathrm{H}_{48} \mathrm{O}$ & 412.6908 & $\begin{array}{l}\text { Unsaturated } \\
\text { phytosterol }\end{array}$ & Food making \\
\hline 25 & 28.074 & 9.25 & Sitosterol & $\mathrm{C}_{29} \mathrm{H}_{50} \mathrm{O}$ & 414.71 & Sterol & $\begin{array}{l}\text { Lowers blood } \\
\text { cholesterol }\end{array}$ \\
\hline 26 & 29.003 & 0.95 & Stigmasta-4,6-diene & $\mathrm{C}_{39} \mathrm{H}_{46} \mathrm{O}$ & 410.686 & Phytosterol & $\begin{array}{l}\text { Precursor of } \\
\text { vitamin } D_{3}\end{array}$ \\
\hline
\end{tabular}


The GC- MS analysis of $G$. ridsdalei revealed the presence of 26 compounds (Fig. 1, Table 1). Hexadecanoic acid showed highest peak (10.16\%) which is the dominant component followed by anthracenedione (9.68\%), maltol (9.35\%), sitosterol $(9.25 \%)$ and oleic acid (5.32\%). Among the identified compounds, hexadecanoic acid is reported to have antioxidant (10) and anti- inflammatory properties (11). Squalene which is a triteterpene, used in cosmetics as a natural moisturiser (1). Recent reports suggest that squalene has chemopreventive activity against colon carcinogenesis $(12,13)$.

Stigmasterol is an unsaturated phytosterol occurring in the plant fats or oils. Stigmasterol is also found in certain vegetables, nuts, legumes, seeds etc. It is used as a precursor in the production of semisynthetic progesterone, an important human hormone that plays a vital role in the regulatory and tissue rebuilding mechanisms related to estrogen effects. It acts as an intermediate in the biosynthesis of estrogens, androgens and corticoids (14). Phytosterols play significant role in cholesterol metabolism in animals and are suitable ingredients of functional foods (15). Anthraquinones or anthracenedione are one of the most important classes of commercial colorants. Natural anthraquinones are preferred as colouring agents for sweets, beverages and other foods (16).

\section{Conclusion}

This is the first report of bioactive components in the roots of $G$. ridsdalei. The result reveals the presence of various bioactive compounds such as sterols, anthraquinone and terpenes and supports the previous reports of therapeutic importance of this endemic, endangered medicinal plant. G. ridsdalei is recommended as a plant of phytochemical and pharmaceutical importance. Further studies can be carried out to isolate the active principle of crude extract as well as to elucidate the effect of extract for various diseases.

\section{Acknowledgements}

The authors are thankful to the Head, Department of Botany, University of Kerala for providing necessary facilities for doing this work and to the University of Kerala for financial support in the form of Junior Research Fellowship and Kerala Forest \& Wild Life Department for granting permission (WL 1020971/2014, 23/6/2014) for collection in the Agasthyamalai Biosphere Reserve.

\section{Conflict of interest}

The authors declare no conflict of interest.

\section{Authors' contribution}

RRN wrote the manuscript and AG helped in manuscript corrections. Field visit, collection and identification was done by AG and RRN.

\section{References}

1. Sermakkani M, Thangapandian V. GC - MS analysis of Cassia italica leaf methanol extract. Asian J Pharm Clin Res 2012;5(2):90- 94.

2. Milne A. Inhalational and local anaesthetics reduce tactile and thermal responses in Mimosa pudicalinn. Masui 1993;1190-1193.

3. Mohanan N, Sivadasan M. Flora of Agasthyamala. Bishen Singh Mahendra Pal Singh, Dehradun 333p; 2002.

4. Zhang A, Sun H, Wang X. Recent advances in natural products from plants for treatment of liver diseases. Eur J Med Chem 2013;63:570-57. https://doi.org/10.1016/ j.ejmech.2012.12.062

5. Han Y, van der Heijden R, Verpoorte R. Biosynthesis of anthraquinone in cell cultures of the Rubiaceae. Plant Cell Tissue Organ Cult. 2001;67:201-20. https://doi.org/10.1023/A:1012758922713

6. Ijinu T P, Anish N, Shiju H, George V, Pushpangadan P. Home gardens for nutritional and primary health security of rural poor of South Kerala. Indian J Traditional Knowledge 2011;10:413-28.

7. Razafimandimbison S G, Bremer B. Nomenclatural changes and taxonomic notes in the tribe Morindeae (Rubiaceae). Adansonia 2011;33:283-309. https://doi.org/ 10.5252/a2011n2a13

8. Sharma M D, Rautela I, Gahlot M, Sharma N, Koshy E P. GC-MS analysis of photo components in juice sample of Indian cane: Saccharum barberi. Int J Pharm Sci Res. 2015;6:5147-53.

9. Stein $S$ E. National Institute of Standards and Technology (NIST), Mass Spectral Database and Software. Version 3.02. Gaithersburg, USA; 1990.

10. Mohan V R. GC- MS determination of bioactive components Eugenia singampattiana. BeddInt $\mathrm{J}$ of Chem Tech Res. 2011;3(3).

11. Thomas E, Aneesh T P, Thomas D G, Anandan R. GC-MS analysis of phytochemical compounds present in the rhizomes of Nervilia aragoana Gaud. Asian J Pharm Clin Res. 2013;3:68-74.

12. Mohan V R, Sudha T, Chidambarampillai S. GC-MS analysis of bioactive components of aerial parts of Kirganelia reticulata Poir (Euphorbiaceae). J Curr Chem Pharm Sci. 2013;3:4.

13. Alagammal $\mathrm{M}$, Tresina $\mathrm{P} \mathrm{S}$, Mohan V R. GC-MS determination of bioactive components of Polygala javana Dc. Int J Curr Pharm Res. 2012;4:42-4.

14. Rao C V, Newmark H L, Reddy B S. Chemopreventive effect of squalene on colon cancer. Carcinogens 1998;19:287-97. https://doi.org/10.1093/carcin/19.2.287

15. Plat J, Mensink R P. Plant stenols and sterol esters in control of blood cholesterol levels- mechanism and safety aspects. Am.J. Cardiol. 2005;4:96(1A):15D-22D.

16. Saastamoinen O. Forest policies, access rights and nonwood forest products in northern Europe, Unasylva 198. Non-wood Forest Products and Income Generation. FAO - Food and Agriculture Organization of the United Nations, in http://www.fao.org/docrep/x2450e/x2450e00.htm, last accessed on 7th August 2012. 